Research Article/Araştırma Makalesi

\title{
The Effect of Educational Information Network Supported Education on the Achievement, Attitude and Motivation of Middle School Students on Equality and Equation
}

\author{
Anıl ÖZBEY * 1 (iD) Timur KOPARAN 2 (iD \\ ${ }^{1}$ Pendik Ömer Nasuhi Bilmen Imam-Hatip Secondary School, Istanbul, Turkey, anilozbey34@gmail.com \\ 2 Zonguldak Bülent Ecevit University, Ereğli Faculy of Education, Zonguldak, Turkey, timurkoparan@gmail.com \\ * Corresponding Author: anilozbey34@gmail.com
}

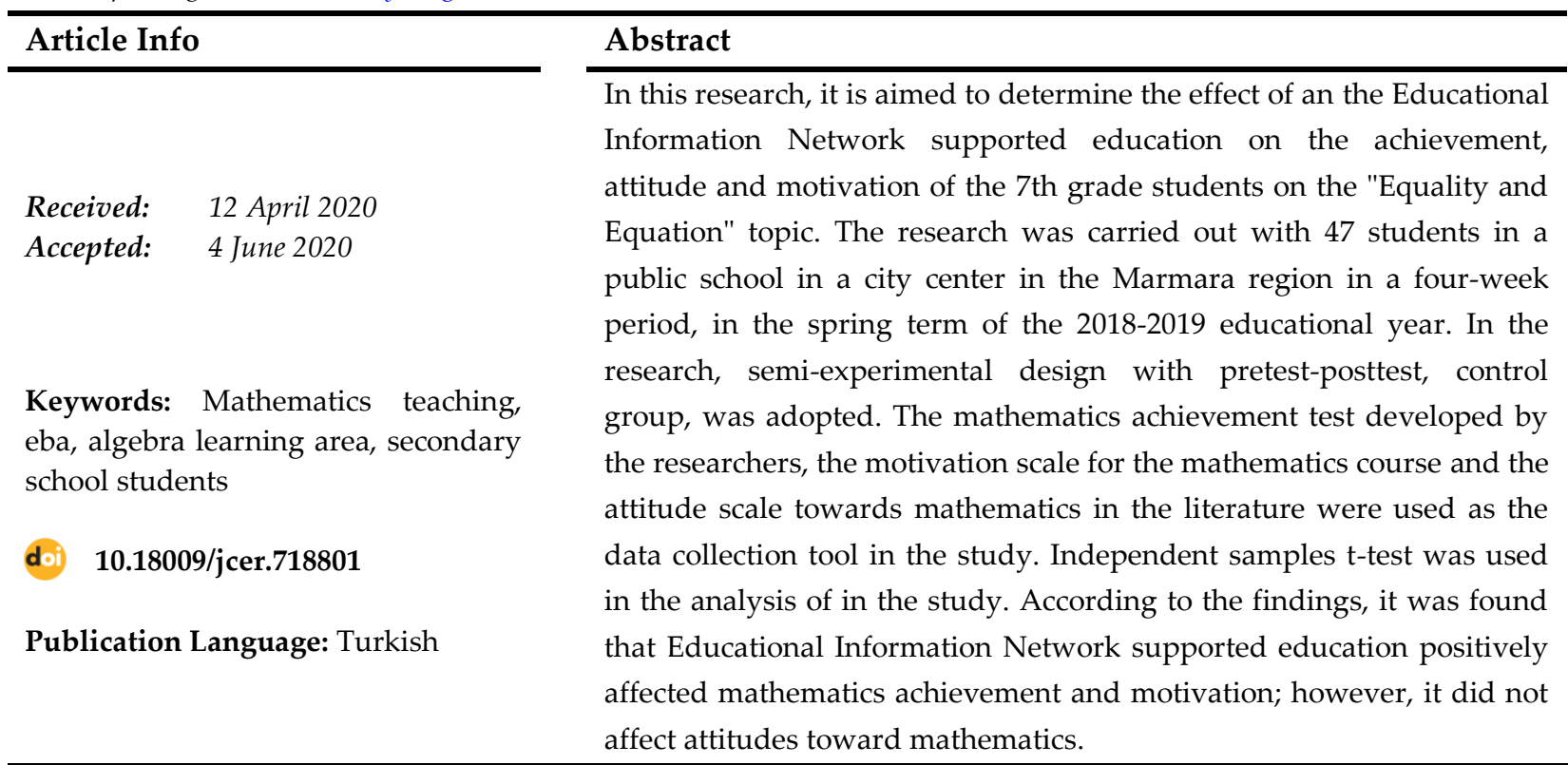

To cite this article: Özbey, A. \& Koparan, T. (2020). Eşitlik ve denklem konusunda eğitim bilişim ağı (eba) destekli öğretimin ortaokul öğrencilerinin başarı, tutum ve motivasyonlarına etkisi. Journal of Computer and Education Research, 8 (16), 453-475. DOI: 10.18009/icer.718801

\section{Eşitlik ve Denklem Konusunda Eğitim Bilişim Ağı (EBA) Destekli Öğretimin Ortaokul Öğrencilerinin Başarı, Tutum ve Motivasyonlarına Etkisi}

\begin{tabular}{ll}
\hline Makale Bilgisi \\
\hline Geliş: & 12 Nisan 2020 \\
Kabul: & 4 Haziran 2020
\end{tabular}

Anahtar kelimeler: Matematik öğretimi, eba, cebir öğrenme alanı, ortaokul öğrencileri

10.18009/jcer.718801

Yayım Dili: Türkçe Öz

Bu çalışma ile Eğitim Bilişim Ağı (EBA) destekli öğretimin ortaokul 7. sınıf öğrencilerinin "Eşitlik ve Denklem" konusundaki başarı, tutum ve motivasyonlarına etkisinin belirlenmesi amaçlanmıştır. Araştırma; 2018-2019 eğitim öğretim yılı bahar döneminde, dört haftalık bir süre ile Marmara bölgesinde bir il merkezinde yer alan bir devlet ortaokulunda, 47 öğrenci ile yürütülmüştür. Araştırmada ön test son test kontrol gruplu yarı deneysel desen benimsenmiştir. Araştırmada veri toplama aracı olarak araştırmacılar tarafından geliştirilen matematik başarı testi, alanyazında bulunan matematik dersine yönelik motivasyon ölçeği ve matematiğe yönelik tutum ölçeği kullanılmıştır. Araştırmada verilerin analizinde bağımsız örneklemler t-testinden yararlanılmıştır. Elde edilen bulgulara göre; EBA destekli öğretimin matematik başarısı ve motivasyonuna olumlu yönde etki ettiği, matematiğe yönelik tutuma ise etki etmediği sonucuna ulaşılmıştır. 


\section{Summary}

\section{The Effect of Educational Information Network Supported Education on the Success, Attitude and Motivation of Middle School Students on Equality and Equation}

\section{Introduction}

The developing technological developments have enabled the today's World to take a different dimension. Today, it has become inevitable to use technology in educational environments. It is important to make the trainings of the students more meaningful and permanent. In these trainings, ICT (Information and Communication Technologies) is seen as an important opportunity tool to increase the quality. ICT is seen as an important aid to teachers in the teaching process (Y1lmaz, Üredi \& Akbaşl1, 2015).

Algebra is one of the sub-learning areas of mathematics. This sub-learning area often contains abstract concepts and requires advanced abstract thinking skills (Altun, 2005). In the research carried out by Ersoy and Erbaş (2003), it is stated that the students have difficulties in the teaching process when they encounter algebra. Students are often afraid to make mistakes in mathematics lessons and therefore they do not want to be actively involved in mathematics lessons, stay in the background in the learning process. Over time, there may be a decrease in students' motivations and attitudes towards mathematics and mathematics lesson due to similar factors (Önal, 2013). The FATİH project has been launched by the MoNE in our country. In order to integrate this project into education, an online social education platform EBA application has been developed. With the EBA platform, all students can continue their learning activities without time and space restrictions. When we look at the literature, it is seen that there are studies (Açlkgöz, 2018; Ertem-Akbaş, 2019; Özbey \& Koparan, 2019; Vahit, 2019; Tekin, 2019) with positive results in mathematics teaching carried out with the support of EBA. Although the number of studies examining the use of EBA contents in mathematics teaching has increased by years, it is seen that it is still not sufficient. It is thought that the results of the effectiveness of EBA-supported 
education should be investigated and it is necessary to carry out this study in order to see the effects on students and the reflection on the teaching environments. The problem statement of this research is: "Is EBA supported learning environment effective?"

\section{Method}

In this research, a semi-experimental design with pretest-posttest control group was adopted. The sample of the study consisted of a total of 47 male students studying in two classes at 7th grade in a state secondary school in the Marmara Region. Since one of the researchers worked in this institution, the study was carried out in this institution with the principle of easy accessibility. One of these two classes was randomly determined as the experimental group and the other as the control group. The implementation continued for four weeks.

Within the scope of the 7th grade mathematics curriculum of the secondary school, the 20-question Mathematics Achievement Test whose validity and reliability studies were carried out was developed by researchers on "Equality and Equation" and applied as a pretest-posttest. The data obtained from the mathematics achievement test and the compliance statistics of the test items were analysed according to the Rasch model by WINSTEPS 3.72 software. As a result of the literature review, "Attitude Scale Towards Mathematics" developed by Önal (2013) and "Motivation Scale for Mathematics Course" developed by Üzel, Uyangör, Hasar and Çakır (2018) were used in the research.

The teaching activities in the experimental group were implemented in the classroom environment with the e-contents on the EBA Course platform, and the activities prepared by the researchers were also used. In the EBA-supported education carried out in the experimental group, all e-contents including “Equality and Equation" were applied within the scope of the 7th Grade Mathematics course in the classroom and no assignments were sent to the students via the EBA platform outside the school. In the learning environment, the EBA portal was accessed via computer and projected to the classroom environment with projector. In the control group, education was continued in the same way as in the previous years. 


\section{Discussion and Conclusion}

After the implementation, it was concluded that EBA supported education has an impact on mathematics achievement. This result obtained from our research is similar to the results of the researches (Açıkgöz, 2018; Ertem-Akbaş, 2019; Özbey \& Koparan, 2019; Vahit, 2019; Tekin, 2019) about EBA use in mathematics education in the literature. In the research conducted by Türkmen and Soybaş (2019), it was concluded that mathematics education, which was carried out using the EBA supported gamification method, had no effect on mathematics achievement. Similarly, in the research conducted by Kelismail (2019), it was concluded that the adoption of EBA supported mathematics teaching in algebra teaching has no effect on mathematics achievement.

After the implementation, it was concluded that EBA supported education has no significant effect on attitude towards mathematics. The results that EBA supported mathematics teaching has an effect on student's attitudes toward mathematics have been reached in the research conducted by Vahit (2019). The conclusion that EBA-supported mathematics teaching has no effect on student's attitudes toward mathematics has also been reached in studies by Kelismail (2019), Türkmen and Soybaş (2019). In this research, the reasons why EBA-supported education does not have an effect on student's attitudes toward mathematics may be the short implementation period and that the students have not experienced EBA supported education before.

After the application, it was concluded that EBA supported education has an effect on motivation for mathematics lesson. Similarly, Ertem-Akbaş (2019) concluded that motivations were effective in increasing students' success as a result of EBA supported mathematics teaching.

In the light of these results, it is recommended to disseminate the EBA-supported mathematics teaching and to have a longer implementation period for the EBA-supported mathematics teaching research. 


\section{Giriş}

Gelişen teknolojik gelişmeler günümüz dünyasının daha farklı bir boyut almasına olanak sağlamıştır. Bu gelişimler eğitim ve öğretim süreçlerini de doğrudan etkilemektedir. Günümüzde eğitim ortamlarında teknolojinin kullanılması kaçınılmaz bir hale gelmiştir. (Pierson, 2001). Eskrootchi ve Oskrochi (2010), okullarda verilen öğretimin etkililiğini ölçmek için yapılan sınavlarda, öğrencilerin öğrendikleri bilgileri uygulama ve açığa çıkarma bağlamında sorunlar yaşadığını belirtmektedir. Öğrencilerin almış oldukları eğitimleri daha anlamlı ve kalıcı hale getirebilmek önemlilik arz etmektedir. Bu eğitimlerde kaliteyi arttırmak için BİT (Bilgi ve İletişim Teknolojileri) önemli bir fırsat aracı olarak görülmektedir. BİT öğretim sürecinde hem öğrencilere hem de öğretmenlere yani öğretim sürecinde yer alan tüm kesime fayda sağlayarak öğretim faaliyetlerine farklı bir boyut katmaktadır (Gomez, Wu \& Passerinic, 2010). Yapılandırmacı öğrenme teorisine göre öğretmenler öğrenme süreçlerinde bilgiyi direkt olarak sunan değil, öğrenmeye yardımcı birer rehber durumundadır. Öğretmenlerin bu rehberlik sürecinde ise BİT önemli bir yardımcı olarak görülmektedir (Yılmaz, Üredi \& Akbaşlı, 2015).

Cebir matematiğin alt öğrenme alanlarından birisidir. Bu alt öğrenme alanı sıklıkla soyut kavramlar barındırır ve ileri derecede soyut düşünebilme becerisi gerektirmektedir (Altun, 2005). Ersoy ve Erbaş (2003), öğrencilerin öğretim sürecinde cebir ile karşılaştıkları andan itibaren zorluklar yaşadığını belirtmektedir. Böylesine zorluklar yaşanan bir alt öğrenme alanına ait konuların öğretimi sürecinde somutlaştırma önem arz etmektedir. Soyutlaşan matematik ile karşı karşıya kalan öğrenciler tarafından matematiğin zor olduğuna dair bir algı oluşabilir. Öğrenciler matematik derslerinde hata yapmaktan sıklıkla korkmakta ve bu sebeple de matematik derslerinde sürece aktif katılan olmak istememekte, öğrenme sürecinde geri planda durmaktadır. Öğrencilerin zamanla benzeri etkenlerden dolayı matematiğe ve matematik dersine yönelik olan motivasyonlarında ve tutumlarında azalmalar olabilmektedir (Önal, 2013). Matematik öğretiminde cebir konularının işlenişinde olabildiğince günlük hayat kavramları ile ilişkilendirmeler yapabilmek önemli bir nokta olabilir. Öğretimin görsel öğeler, animasyonlar, somut materyaller, teknolojik materyaller ile desteklendiği durumlarda öğretimin etkililiğinin daha anlamlı olması beklenir (Demirel \& Yağc1 2006).

Öte yandan ülkemizde her coğrafi bölgede aynı seviyede gelişmişlik düzeyine sahip olunmaması, her bölgede internet erişimine ulaşımın kolay olmaması, her bireyin teknolojiye 
erişilebilirliğinin aynı olmaması gibi nedenler eğitimde fırsat eşitsizliğine sebep olmaktadır (Alkan, Bilici, Akdur, Temizhan \& Çiçek, 2011). Tüm bu eşitsizlikleri en aza indirmek amacı ile ülkemizde MEB tarafından FATIHH projesi hayata geçirilmiştir. Bu projenin eğitime entegrasyonunu sağlamak üzere de çevrimiçi bir sosyal öğretim platformu olan EBA uygulaması geliştirilmiştir. Uzaktan eğitim yüz yüze eğitime bir alternatif olarak görülebilir. Yüz yüze öğretim faaliyetlerinin gerçekleştirilemeyeceği zamanlarda uzaktan öğretime başvurulabilmektedir. Halbuki Yılmaz ve Düğenci (2010) uzaktan eğitim faaliyetlerinin de yüz yüze eğitim faaliyetleri kadar etkili olduğunu ve uzaktan eğitimin yüz yüze eğitimin bir alternatifi olarak görülmemesi gerektiğini belirtmektedir. EBA ile gerektiğinde öğretim faaliyetleri uzaktan eğitim modeli ile de yürütülebilmektedir.

EBA platformu ile tüm öğrenciler zaman ve mekân sınırlaması olmadan öğrenme faaliyetlerine devam edebilmektedir. EBA portalı (http://www.eba.gov.tr/) adresinden erişim sağlanabilen; okul öncesi, ilköğretim ve ortaöğretimde öğretim süreçlerinde yer alan öğretmen, öğrenci ve eğitim fakültelerinde görev yapan akademisyen ve öğrenim gören üniversite öğrencilerinin erişimine açık olan tamamen ücretsiz bir platformdur. Öğretmenler ve öğrenciler EBA'yı öğrenme ortamlarında kullanabileceği gibi öğrenme ortamı dışında da rahatlıkla kullanabilirler. Alanyazında yer alan araştırmalar incelendiğinde EBA'nın öğretim süreçlerinde kullanılmasının; öğretimde somutlaştırma sağlama, öğretimi destekleme, tam öğrenme sağlama, anlaşılamayan yerleri tekrar etme, pekiştirme, soru çözme gibi birçok fayda sağladığı belirtilmektedir (Türker \& Güven, 2016). Teknolojik bir öğretim materyali olan EBA platformunda bulunan EBA-Ders bölümünde öğretim programlarında yer alan derslere ait konu anlatımları, alıştırmalar, tarama testleri, çalışma soruları, etkinlikler, özet çalışma yaprakları, öğretmenlere özel öğretim içerikleri gibi birçok e-içerikler mevcuttur. EBA platformunda yer alan e-içerikler öğretmenler ve öğrenciler tarafından öğretimde etkili olarak kullanıldığında öğrenme faaliyetlerinde istenilen sonuçlara ulaşılabilir. EBA platformu dört ana modülden oluşmaktadır. Bu modüller; Ana sayfa, Sayfam, Hızlı Erişim ve Yardım'dır. Sayfam bölümü; öğretim programlarında yer alan tüm dersler ve etkinlikler ile ilgili, öğretimi desteklemek üzere hazırlanmış konu anlatımları, video etkinlikler, çalışma yaprakları gibi e-içeriklerden oluşmaktadır. EBA platformunda yer alan bütün bölümlerdeki içerikler uzman kontrolünden geçmektedir. Aşağıda EBA portalı Sayfam modülünde yer alan EBA ders bölümünde içeriklerden bir tanesine ait görsel Şekil 1'de verilmiştir. 


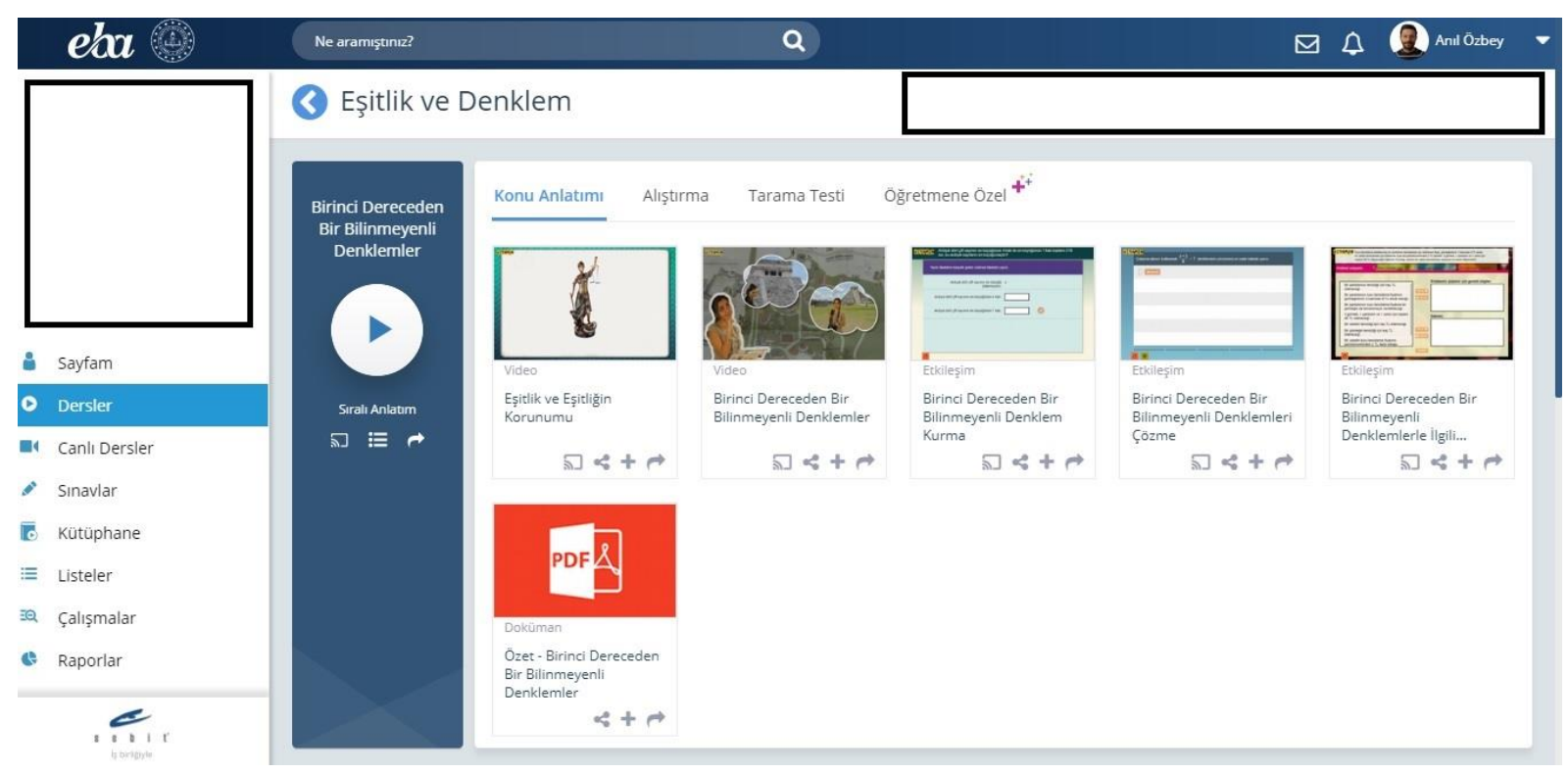

Şekil 1. EBA-Ders bölümü

Şekil 1'de görüldüğü gibi EBA Ders bölümünde her ders ve her konu için öğretime yardımcı kaynaklar bulunmaktadır. Bu bölümden öğretmenler; öğrencileri ile; canlı dersler gerçekleştirebilmekte, öğretim materyallerini ödev olarak tanımlayabilmekte, etkinlik ya da çalışma sorularına ait performanslara ilişkin sistemden geri bildirim raporu alabilmektedir.

Literatürde EBA destekli olarak gerçekleştirilen matematik öğretimi üzerine yapılan çalışmaların son yıllarda artış gösterdiği görülmektedir. Açıkgöz (2018), EBA destekli matematik öğretiminin ortaokul öğrencilerinin "Cisimlerin Farklı Yönden Görünümleri” konusunda EBA destekli matematik öğretiminin öğrencilerin matematik başarıları üzerinde anlamlı ve olumlu yönde bir etki yarattığı, öğrencilerin EBA destekli matematik öğretimiyle ilgili olumlu görüşlere sahip olduğu sonucuna ulaşmıştır. Özbey ve Koparan (2019), EBA destekli matematik öğretiminin ortaokul öğrencilerinin “Doğrusal Denklemler ve Eğim” konusunda matematik başarıları üzerinde etkili olduğu sonucuna ulaşmıştır. Benzer şekilde Ertem-Akbaş (2019), EBA destekli matematik öğretiminin öğrencilerinin "Kesirler" konusundaki akademik başarıları üzerinde etkili olduğu sonucuna ulaşmıştır. Vahit (2019), EBA destekli matematik öğretiminin “Doğal Sayılar ve Doğal Sayılarla İşlemler" konusunda öğrencilerinin matematik başarısı ve matematiğe yönelik tutumları üzerinde etkili olduğunu, teknolojiye yönelik tutumlarında etkili olmadığı sonucuna ulaşmıştır. Tekin (2019), EBA destekli matematik öğretiminin "Oran ve Orantı" konusunun öğretiminde öğrencilerin matematik başarıları üzerinde anlamlı düzeyde etkili olduğu, üst biliş davranışlar üzerinde ise etkili olmadığı sonucuna ulaşmıştır. Ankay (2019), EBA destekli matematik öğretiminin “Kesirlerle Toplama ve Çıkarma İşlemleri” konusunda öğrencilerin matematik başarısı ve 
matematiğe yönelik tutumları üzerinde anlamlı düzeyde bir etkisinin olmadığı sonucuna ulaşmıştır.

\section{Araştırmanın Amacı}

Tüm dünyada yaşanan virüs salgını nedeniyle alınan tedbirler çerçevesinde okullarda eğitim öğretime uzun süre ara verilmiştir. Bu dönemde ülkemizde çeşitli güncellemeler ile sürekli geliştirilen EBA dijital platformu ve televizyon kanalları sayesinde öğrenciler derslerini takip edebilme imkânı bulmuşlardır. Uzaktan eğitimin ve uzaktan eğitim ile desteklenen öğrenme ortamlarının önemi bu süreçte çok daha iyi anlaşılmıştır. Bununla birlikte öğrenmenin zaman ve mekândan bağımsız olduğu, teknolojinin öğrenme süreçlerine giderek daha fazla girdiği bu dönemde oluşturulan öğrenme ortamlarının ve etkililiğinin ortaya konulmasına ihtiyaç duyulmaktadır.

Bu çalışma ile “Eşitlik ve Denklem” konusunun öğretiminde EBA destekli öğrenme ortamı oluşturulması, oluşturulan bu öğrenme ortamının öğrencilerin başarı, tutum ve motivasyonlarına etkisinin incelenmesi amaçlanmıştır. $\mathrm{Bu}$ amaç doğrultusunda “EBA destekli öğrenme ortamı etkili midir? “ problemi ve

1. Gruplar arası "Eşitlik ve Denklem" konusu başarı puanları arasında istatistiksel olarak anlamlı bir fark var mıdır?

2. Gruplar arası matematiğe yönelik tutum puanları arasında istatistiksel olarak anlamlı bir fark var mıdır?

3. Gruplar arası matematik dersine yönelik motivasyon puanları arasında anlamlı bir farklılık var mıdır? alt problemlerine cevap aranmıştır.

\section{Yöntem}

\section{Araştırmanın Deseni}

$\mathrm{Bu}$ araştırmada, nicel araştırma yöntemlerinden ön test son test kontrol gruplu yarı deneysel desen benimsenmiştir. Deneysel desenlerde, değişim içinde olması beklenen etkenler uygun koşullar altında planlı bir şekilde gözlemlenir (Fraenkel \& Wallen, 2006). Grupların her zaman rastgele dağıtılmasının mümkün olmadığı durumlarda, mevcut olan gruplarda gerçek deneysel desen yerine yarı deneysel desen farklı bir seçenek olarak kullanılabilir (Çepni, 2007). Araştırmada kullanılan deseninin simgesel görünümü Tablo 1'de verilmiştir. 
Tablo 1. Araştırma deseni

\begin{tabular}{llll}
\hline Grup & Ön Test & İşlem & Son Test \\
\hline \multirow{2}{*}{ Deney } & Matematik Başarı Testi-1 & & Matematik Başarı Testi-2 \\
& $\begin{array}{l}\text { Matematiğe Yönelik Tutum Ölçeği-1 } \\
\text { Matematik Dersine Yönelik } \\
\text { Motivasyon Ölçeği-1 }\end{array}$ & $\begin{array}{l}\text { EBA destekli } \\
\text { öğretim }\end{array}$ & $\begin{array}{l}\text { Matematiğe Yönelik Tutum Ölçeği-2 } \\
\text { Matematik Dersine Yönelik } \\
\text { Motivasyon Ölçeği-2 }\end{array}$ \\
\hline \multirow{2}{*}{ Kontrol } & Matematik Başarı Testi-1 & & Matematik Başarı Testi-2 \\
& Matematiğe Yönelik Tutum Ölçeği-1 & Mevcut öğretim & Matematiğe Yönelik Tutum Ölçeği-2 \\
& Matematik Dersine Yönelik & yöntemi & Matematik Dersine Yönelik \\
& Motivasyon Ölçeği-1 & & Motivasyon Ölçeği-2 \\
\hline
\end{tabular}

\section{Katılımcilar}

Araştırmanın örneklemi Marmara Bölgesi'nde yer alan bir il merkezine bağlı devlet ortaokulunda 7.sınıf düzeyinde iki sınıfta öğrenim gören toplam 47 erkek öğrenci ile oluşturulmuştur. Araştırmacılardan birinin görev yaptığı kurum olmasından dolayı kolay ulaşılabilirlik ilkesiyle bu kurumda uygulama yapılmıştır. Bu iki sınıftan rastgele olarak birisi deney grubu öteki de kontrol grubu olarak belirlenmiştir. Tablo 2'de çalışmaya katılan öğrencilere ait veriler sunulmuştur.

Tablo 2. Çalışma grubu dağ

\begin{tabular}{ll}
\hline Grup/Cinsiyet & Toplam \\
\hline Deney & $25(\% 53)$ \\
\hline Kontrol & $22(\% 47)$ \\
\hline
\end{tabular}

Veri Toplama Araçları

Araştırmada veri toplamak üzere Matematik Başarı Testi, Matematiğe Yönelik Tutum Ölçeği, Matematik Dersine Yönelik Motivasyon Ölçeği kullanılmıştır. Veri toplama araçlarına ait bilgiler aşağıda verilmiştir.

\section{Matematik Başarı Testi}

Matematik başarı testi için ilk olarak 7. sınıf matematik öğretim programı "Eşitlik ve Denklem" konusu kazanımları, literatürde bu konuda yapılan çalışmalar, "Parasız Yatılılık ve Bursluluk Sınavı" ve "Seviye Belirleme Sınavı" çıkmış soruları, MEB destekleme ve yetiştirme kursları kazanım kavrama testleri, soru bankaları incelenmiş ve 40 adet çoktan seçmeli sorunun yer aldığı soru havuzu oluşturulmuştur. Bu sorular iki alan uzmanına ve iki matematik öğretmenine inceletilerek görüşleri alınmıştır. Görüşler doğrultusunda öğretim programına uygunluk (2), kapsam geçerliği (5), kazanımlara göre dengeli dağılım (4), süre (6), zorluk (3) kıstaslarında gelen dönütler çerçevesinde teste 20 soruluk son hali verilmiştir . Tablo 3'te testte yer alan maddelerin kazanımlara göre dağılımı ve yüzdeleri verilmiştir. 
Tablo 3. Başarı Testi Kazanımları

\begin{tabular}{llc}
\hline Kazanımlar & Test Madde No & $\mathbf{\%}$ \\
\hline Kazanım 1: Eşitliğin korunumu ilkesini anlar. & $1,6,13,19,20$ & 25 \\
\hline $\begin{array}{l}\text { Kazanım 2: Birinci dereceden bir bilinmeyenli denklemleri tanır ve verilen gerçek } \\
\text { hayat durumlarına uygun birinci dereceden bir bilinmeyenli denklem kurar. }\end{array}$ & $2,3,5,9,12$ & 25 \\
\hline Kazanım 3: Birinci dereceden bir bilinmeyenli denklemleri çözer. & $4,7,8,14,15,18$ & 30 \\
\hline $\begin{array}{l}\text { Kazanım 4: Birinci dereceden bir bilinmeyenli denklem kurmayı gerektiren } \\
\text { problemleri çözer. }\end{array}$ & $10,11,16,17$ & 20 \\
\hline
\end{tabular}

Matematik başarı testinde yer alan maddelerin bir arada uyumluluğunu incelemek, istenen amaca uygunluğunu belirlemek amacıyla matematik başarı testinden elde edilen verilerle test maddelerinin uyum istatistikleri Rasch modeline göre analiz edilmiştir. WINSTEPS 3.72 yazılımı ile analizler gerçekleştirilmiştir. İlgili teste ait madde uyum istatistikleri analiz sonuçları Tablo $4^{\prime}$ te verilmiştir.

Tablo 4. Başarı testi madde uyum istatistikleri

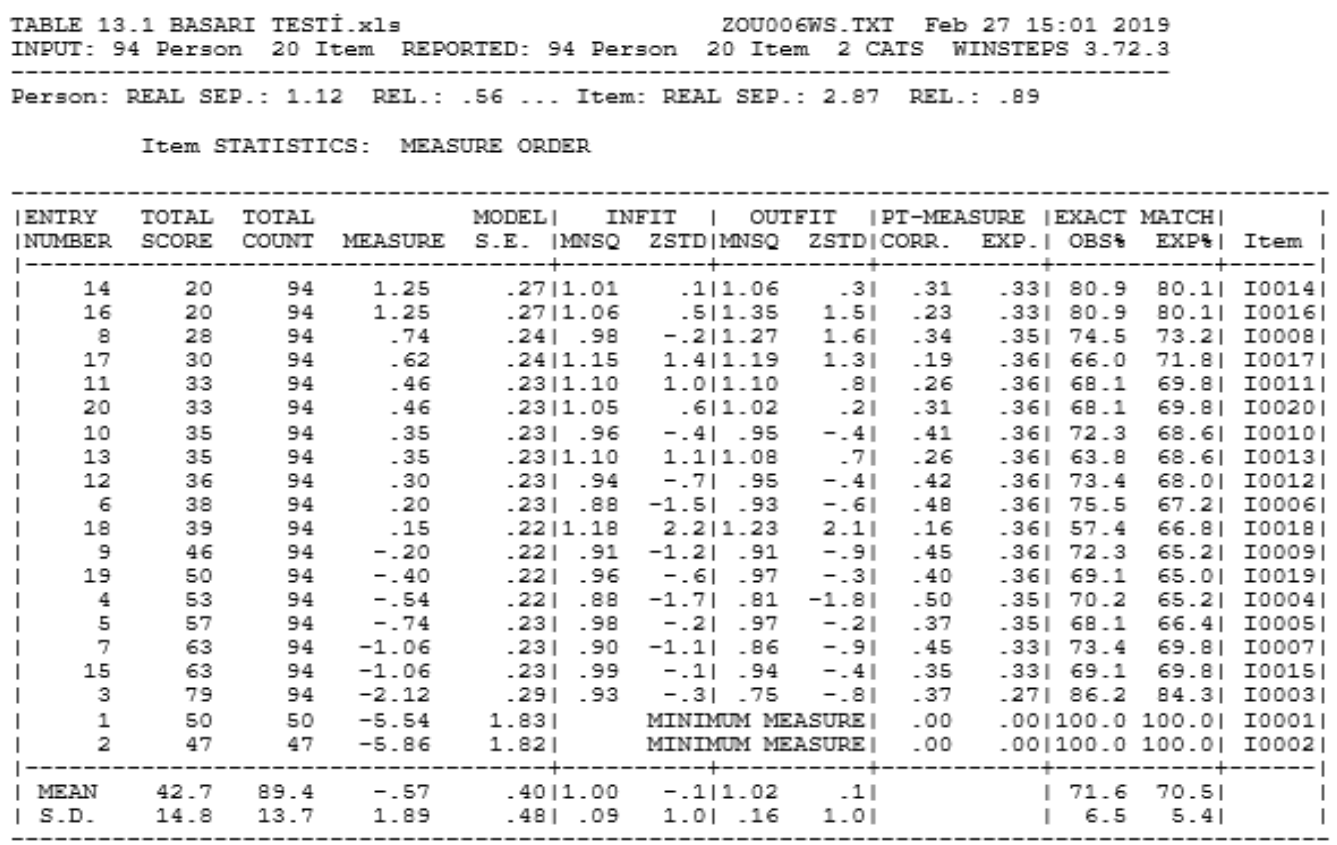

Bond ve Fox (2007)'a göre maddelerin kabul edilebilirliği için uygunluk içi (INFIT MNSQ) ve uygunluk dışı (OUTFIT MNSQ) değerleri 0,5 ile 1,7 arasında olmalıdır. En ideal değer ise 1,00'dir. Tablo 4'te görüldügü gibi ölçekte yer alan hiçbir maddenin kabul edilebilir uyum sınırları dışında kalmadığı görülmektedir. Başarı testinin örnekleme uygulanması sonucunda maddelerin zorluk ölçümleri ölçüm (MEASURE) sütununda görülmektedir. Madde zorluk ölçümleri incelendiğinde öğrenciler için en zor soruların 14 ve 16 . soru, en kolay soruların ise 1 ve 2. soru olduğu görülmektedir. Matematik başarı testinde yer alan sorulardan bazı örnekler Ek 1'de, araştırmada kullanılan etkinliklerden bazı örnekler Ek 2'de sunulmuştur. 


\section{Matematiğe Yönelik Tutum Ölçeği}

Araştırmada literatür taraması sonucu Önal (2013) tarafından geliştirilmiş olan "Matematiğe Yönelik Tutum Ölçeği" kullanılmıştır. İlgili ölçek, 5'li likert tipi olup, 4 faktör ve 22 maddeden oluşmaktadır. Ölçek "Tamamen Katılıyorum", ... , "Kesinlikle Katılmıyorum" şeklinde oluşturulmuştur. Ölçeğe ait Cronbach's alpha katsayısı Önal (2013) tarafından 0,90 olarak belirlenmiştir. Ölçekte yer alan faktörler sırası ile "İlgi", "Kayg1", "Çalışma" ve "Gereklilik" şeklindedir. Ölçekte yer alan 22 maddenin 11'i olumlu ve 11'i olumsuz maddeden oluşmaktadır.

\section{Matematik Dersine Yönelik Motivasyon Ölçeği}

Araştırmada literatür taraması sonucu Üzel, Uyangör, Hasar ve Çakır (2018) tarafından geliştirilmiş olan "Matematik Dersine Yönelik Motivasyon Ölçeği" kullanılmıştır. İlgili ölçek, 5'li likert tipi şeklinde olup, "Hiç Katılmıyorum", ... , "Tamamen Katılıyorum" şeklinde oluşturulmuştur. Ölçek 3 faktörlü olup, bu faktörler "Performansa Yönelik Motivasyon", "Matematiksel Doyum" ve "Motivasyonsuzluk" şeklindedir. Ölçekte 18'i olumlu ve 8'i olumsuz olmak üzere 26 madde yer almaktadır. Ölçeğin Cronbach's alpha katsayısı Üzel vd. (2018) tarafından 0,88 olarak belirlenmiştir.

\section{İşlem}

Uygulama ortaokul 7.sınıf matematik öğretim programında yer alan “Eşitlik ve Denklem“ konusunda deney ve kontrol grubu ile gerçekleştirilmiştir. Araştırmacılardan bir tanesi aynı zamanda bu iki sınıfın da dersini yürüten öğretmendir. Gruplara matematik başarı testi, matematiğe yönelik tutum ölçeği ve matematik dersine yönelik motivasyon ölçeği uygulama öncesinde ön test olarak uygulanmıştır. Ön testlerden elde edilen verilerin analizleri yapıldıktan sonra grupların matematik başarısı, matematiğe yönelik tutum ve matematik dersine yönelik motivasyon değişkenlerinin her biri açısından denk oldukları görülmüş ve uygulamaya başlanmıştır. Uygulama dört hafta (20 ders saati) ile sınırlandırılmıştır. Deney grubunda öğretim faaliyetleri EBA Ders platformunda yer alan eiçerikler, araştırmacılar tarafından hazırlanan etkinlikler ve MEB ders kitabı ile gerçekleştirilmiştir. Deney grubunda gerçekleştirilen EBA destekli öğretimde ortaokul 7.sınıf matematik dersi bölümünde yer alan ve "Eşitlik ve Denklem“ konusunu içeren tüm eiçerikler sınıf ortamında uygulanmış, öğrencilere okul dışında EBA platformu üzerinden herhangi bir ödev gönderimi ya da paylaşım yapılmamıştır. Öğrenme ortamında EBA portalına bilgisayar üzerinden erişim sağlanmış ve projeksiyon ile sınıf ortamına yansıtma 
yapılmıştır. Öğrenme ortamında öğrencilerin kimi zaman EBA öğrenme içeriklerini sınıf ortamında bizzat kendilerinin yapmasına olanak sağlanmıştır. Kontrol grubunda ise öğretime önceki yıllarda işlenen şekilde devam edilmiştir. Deney grubunda ilk hafta gerçekleştirilen öğretim faaliyetleri aşağıda açıklanmıştır.

Deney grubunda uygulamanın ilk dersinde EBA portalı öğrencilere tanıtılmış; öğrencilerin sisteme nasıl giriş yapacakları, portalda yer alan ders içeriklerini ve etkinliklerine nasıl ulaşacakları hakkında bilgi verilmiştir. Ardından ikinci derste EBA Ders bölümü ortaokul 7.sınıf matematik dersi bölümünde yer alan ve ilgili konuyu içeren “Eşitlik ve Eşitliğin Korunumu“ konu anlatımı videosunu izletilmiş, video sonrasında öğrencilerle soru cevap yapılmasına olanak sağlayan bir tartışma ortamı oluşturulmuştur. Öğrencilerden gelen talep sonrasında video etkinlik tekrar sınıf ortamında izlenilmiştir. Sonrasında ise ders kitabında yer alan ilgili konu ile ilgili ders içerikleri incelenmiştir. Ardından dersin sorumlusu olan araştırmacı tarafından konu anlatımı gerçekleştirilmiştir. Daha sonra araştırmacılar tarafından hazırlanan Etkinlik-1'in sınıf ortamında öğrenciler tarafından yapılması istenmiştir. Sonraki derslerde ise EBA Ders bölümünde yer alan "Eşitlik ve Denklem" tarama testi öğrenciler tarafından gönüllük esasına göre sınıf ortamında çözülmüştür. Ardından araştırmacılar tarafından hazırlanan Etkinlik-2'nin sınıf ortamında öğrenciler tarafından yapılması istenmiş ve böylece deney grubunda bir haftalık öğrenme faaliyetleri tamamlanmıştır. Diğer haftalarda da deney grubunda yukarıda açılananlara paralel olarak öğretim faaliyetleri sürdürülmüştür.

Araştırmanın ikinci haftasında deney grubunda “Birinci dereceden bir bilinmeyenli denklemleri tanır ve verilen gerçek hayat durumlarına uygun birinci dereceden bir bilinmeyenli denklemleri kurar." kazanımının işlenmesine ait gerçekleştirilen bir derste öğrencilere "Birinci Dereceden Bir Bilinmeyenli Denklem Kurma" video etkinliğinin giriş kısmı öğrencilere izletilmiştir. Sonrasında araştırmacı tarafından öğrencilere "Nasıl?", "Neden?", "Niçin?", "Siz olsaydınız şimdi ne yapardınız?" gibi sorular yönlendirilerek öğrencilerin konu hakkında matematiksel düşüncelerinin harekete geçirilmesi amaçlanmıştır. Sonrasında ise sınıftan gönüllük esasına göre istekli olan öğrenciler seçilerek öğrencilerin sınıf ortamında etkinliği yapmasına ait açıklama ve birkaç görsel Şekil 2'de verilmiştir. 
Birinci Dereceden Bir Bilinmeyenli Denklem Kurma
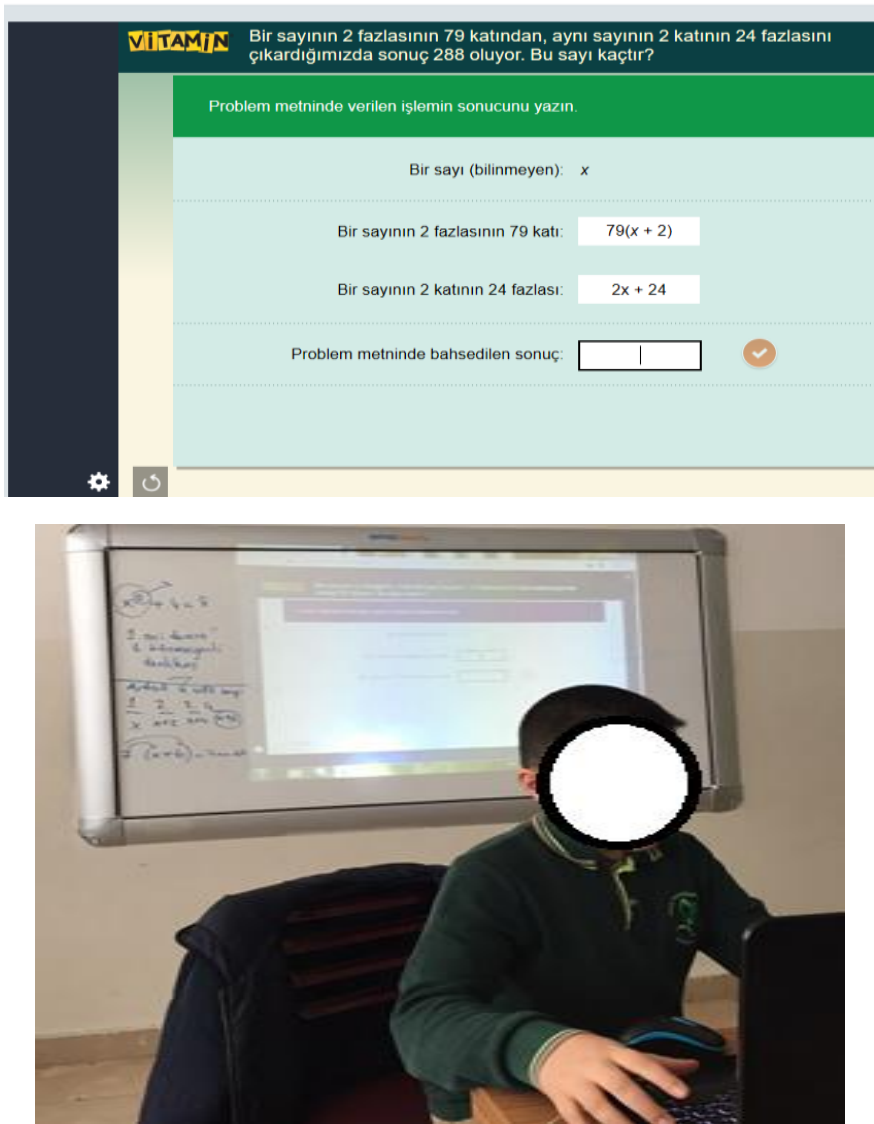

Şekil 2. Denklem kurma kazanımına ilişkin EBA platformu kullanımı

Şekil 2'de görülen etkinlikte verilen sözel ifadelerin değişkenler kullanarak matematiksel ifadelere dönüştürülmesi, birinci dereceden bir bilinmeyenli denklem kurması ve denklemi sağlayan bilinmeyenin değerinin bulunması beklenmektedir. Etkinlikte verilen soruda bir sayının 2 fazlasının 79 katı ile aynı sayının 2 katının 24 fazlasının birbirine eşit olduğu belirtilmiştir. EBA platformunda öğrencinin vermiş olduğu yanita göre yapılan işlemin doğru ya da yanlış olduğuna dair sesli olarak dönüt verilmektedir. Bu etkinlikte öğrencilerden verilen sözel ifadeler ile birinci dereceden bir bilinmeyenli denklem içeren ifadeleri oluşturma ve bu denklemin sonucunun çözülmesi beklenmektedir.

Benzer şekilde "Birinci dereceden bir bilinmeyenli denklemleri çözer." kazanımını içeren bir dersin işlenmesi sürecinde öğrencilere “Denklem Çözümünde Hatalı Olan Adımı Bulma" isimli alıştırmanın sınıf ortamında yapılması için öncelikle alıştırmanın giriş kısmı öğrencilere izletilmiştir. Sonrasında alıştırmanın giriş ekranında yer alan matematiksel ifadeleri öğrencilerin görmesi sağlandıktan sonra öğrencilere "Nasıl?", "Neden?", "Niçin?" soruları sorularak öğrencilerin matematiksel düşüncelerinin harekete geçirilmesi amaçlanmıştır. Sınıftan gönüllük esasına göre istekli olan öğrenciler seçilerek sınıf ortamında etkinliği yapmasına ait birkaç görsel Şekil 3'te verilmiştir. 
( Denklem Çözümünde Hatalı Olan Adımı Bulma
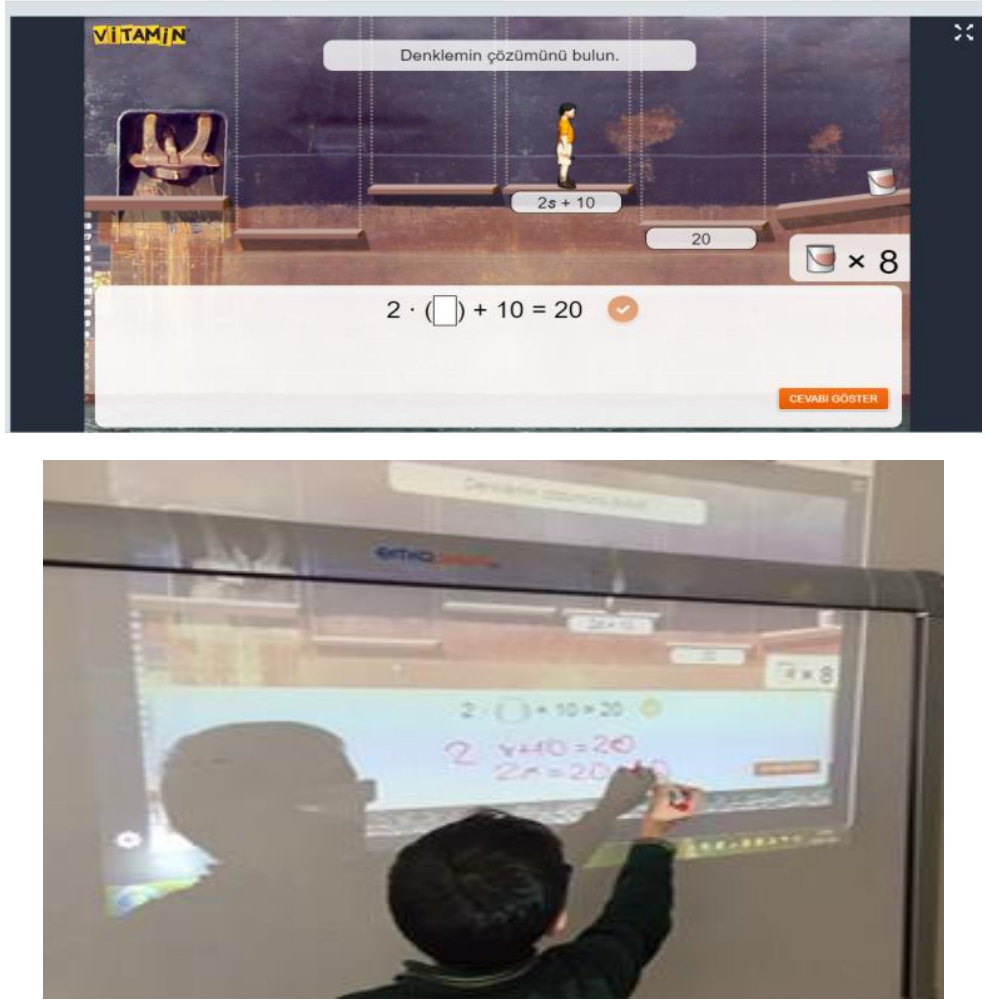

Şekil 3. Denklem çözme kazanımına ilişkin EBA platformu kullanımı

Şekil 3'te görülen etkinlikte Ali isimli bir kahramanın platformların üzerinden geçişinin sağlanarak boya kutularına ulaşması istenmekte olup platform arasında geçiş yapabilmek için etkinlikte verilen denklemlerin çözümünü içeren bilinmeyen değerlerinin bulunması ve bu denklemlerin çözümlerinde verilen adımlardan hatalı olanın belirlenmesi amaçlanmıştır. Bilinmeyenin değerinin yanlış bulunması veya denklem çözümünde hatalı adımı belirlemede yanlış seçeneğin seçilmesi sonucunda ya da cevabı göster seçeneğine basılması durumunda boya kutularından birisi kaybedilecektir. Etkinliğin sonunda öğrencilerin olabildiğince az yanlış yaparak en fazla sayıda boya kutusuna erişebilmesi beklenmektedir. Bu şekilde soyut bir konu olan denklem çözümü konusunun oyun yolu ile öğretimi konunun somutlaştırılması için önemli bir adım olacaktır.

Kontrol grubunda ilk hafta gerçekleştirilen faaliyet açıklanmıştır. İlk dersin giriş kısmında öğrencilere çevremizde ve günlük hayatta sıklıkla görülen eşitlik kavramı ile ilgili örnekler verilmiştir. Konuya giriş ve hazırlık aşamasında MEB ders kitabındaki gündelik hayatla ilişki içeren bir görselin öğrenciler tarafından incelenmesi istenmiştir. Ardından öğrenciler ile konu üzerine tartışma ortamı oluşturulmuş ve sonrasında dersin sorumlusu araştırmacı tarafından öğrencilere özet olacak şekilde bir konu anlatımı yapılmıştır. Uygulamanın ilk iki dersi özet konu anlatımı, ders kitabında yer alan başlangıç 
etkinliklerinin yapılması ve örneklerin incelenmesi ile tamamlanmıştır. Sonraki derste, ders kitabındaki etkinlikler ve uygulamalar öğrenciler ile sınıf ortamında yapılmıştır. Ders kitabında yer alan etkinlik ve uygulamalar yaptırılırken öğrencilerin iki kişilik gruplara ayrılması istenmiştir. Gruplara ayırma işlemi yapılması ile öğrenci grupları arasındaki olabilecek farklılıkların tespit edilmesi ve bu sayede olası kavram yanılgılarının önüne geçilmesi amaçlanmıştır. Gruplarda yer alan öğrencilerin uygulamaya ilişkin cevapları sınıf ortamında incelenmiştir. Bir sonraki derste ise ders kitabındaki ilgili konuya ait “Öğrendiklerimizi Uygulayalım” etkinliğinin yapılması istenmiştir. İlk haftanın son dersinde ise işlenen konular özetlenmiştir. Diğer haftalarda da kontrol grubunda yukarıdaki açıklamalara paralel olarak öğretim faaliyetleri sürdürülmüştür. Son hafta öğrencilere ilgili konuyu içeren ünite sonu değerlendirme testi sınıf ortamında çözdürülmüş ve birlikte cevaplandırılmıştır.

\section{Veri Analizi}

$\mathrm{Bu}$ araştırmada matematik başarı testi, matematiğe yönelik tutum ölçeği ve matematik dersine yönelik motivasyon ölçeği ile toplanan nicel verilere ait parametrik testlerin yapılabilmesi için öncelikle toplanan verilere ait normallik testleri yapılmıştır.

Matematik başarı testi kullanılarak uygulama sırasında testte yer alan çoktan seçmeli 20 soru için doğru olan yanıtlar 5, yanlış olan yanıtlar ise 0 puan olarak belirlenmiştir. Testten alınabilecek en yüksek puan değeri 100, en düşük puan değeri ise 0 'dır. Matematiğe yönelik tutum ölçeği kullanılarak uygulama sırasında ölçekte yer alan olumlu maddelerden başlanarak olumsuz maddelere doğru azalan "Tamamen Katılıyorum” 5, .. ,'Kesinlikle Katılmıyorum" 1 olacak şekilde puanlar belirlenmiştir. Ölçek sonucunda alınabilecek en yüksek puan 110, en düşük puan ise 22'dir. Matematik dersine yönelik motivasyon ölçeği kullanılarak uygulama sırasında ölçekte yer alan olumlu maddelerden başlanarak olumsuz maddelere doğru azalan "Tamamen Katılıyorum" 5, ..., "Hiç Katılmıyorum" 1 olacak şekilde puanlar belirlenmiştir. Ölçek sonucunda alınabilecek en yüksek puan 130, en düşük puan ise $26^{\prime}$ dır. Araştırmada matematiğe yönelik tutum ölçeği ve matematik dersine yönelik motivasyon ölçeğinde yer alan faktörler kullanılmayıp ölçeklerin bütününden elde edilen veriler kullanılmıştır. Araştırmanın üç alt problemine yönelik matematik başarı testi, matematiğe yönelik tutum ölçeği ve matematik dersine yönelik motivasyon ölçeğinden elde edilen verilerle parametrik testlerin yapılabilmesi için dağılımın normal dağılıma sahip 
olması gerektiği varsayımının sağlanması gerekmektedir. Bu amaçla ile elde edilen verilerle normallik testleri yapılmıştır. Elde edilen verilere ait bulgular Tablo 5'te gösterilmiştir.

Tablo 5. Ön test ve son testlere ait normallik değerleri

\begin{tabular}{|c|c|c|c|c|c|}
\hline Grup & Test & $\begin{array}{l}\text { Çarpıklık } \\
\text { Değeri }\end{array}$ & $\begin{array}{l}\text { Çarpıklığın } \\
\text { Standart Hatası }\end{array}$ & $\begin{array}{l}\text { Basıklık } \\
\text { Değeri }\end{array}$ & $\begin{array}{l}\text { Basıklığın } \\
\text { Standart Hatası }\end{array}$ \\
\hline Deney & \multirow[t]{2}{*}{ Başarı Ön Test } & 137 & ,464 &,- 383 & ,902 \\
\hline Kontrol & & ,626 & ,491 & 1,179 & ,953 \\
\hline Deney & \multirow[t]{2}{*}{ Başarı Son Test } & 206 & 464 &,- 705 & ,902 \\
\hline Kontrol & & ,509 & 491 &,- 074 & ,953 \\
\hline Deney & \multirow{2}{*}{$\begin{array}{l}\text { Tutum Ölçeği } \\
\text { Ön Test }\end{array}$} & 137 & ,553 &,- 086 & ,902 \\
\hline Kontrol & & 626 & 633 & $-1,090$ & ,953 \\
\hline Deney & \multirow{2}{*}{$\begin{array}{l}\text { Tutum Ölçeği } \\
\text { Son Test }\end{array}$} & 206 & , 126 &,- 030 & ,902 \\
\hline Kontrol & & ,509 & 1,216 & 1,801 & ,953 \\
\hline Deney & \multirow{2}{*}{$\begin{array}{l}\text { Motivasyon } \\
\text { Ölçeği Ön Test }\end{array}$} &,- 903 & 464 & 834 & ,902 \\
\hline Kontrol & & ,336 & 491 &,- 610 & ,953 \\
\hline Deney & \multirow{2}{*}{$\begin{array}{l}\text { Motivasyon } \\
\text { Ölçeği Son Test }\end{array}$} & ,022 & 464 & $-1,103$ & ,902 \\
\hline Kontrol & &,- 077 & 491 & ,103 & ,953 \\
\hline
\end{tabular}

George ve Mallery (2010)'e göre bir dağılımın normallik şartını sınamak için çarpıklık ve basıklık değerlerine bakılabilir ve bu değerlerin \pm 2 aralığında olması halinde verilerin normal dağılım gösterdiği belirtilmektedir. Tablo 5'te görüldüğü gibi elde edilen verilerin normal dağılım gösterdiği görülmüş ve matematik başarı testi, matematiğe yönelik tutum ölçeği ve matematik dersine yönelik motivasyon ölçeğinden elde edilen verilere parametrik testlerden olan bağımsız örneklemler t-testi uygulanmıştır.

\section{Bulgular}

$\mathrm{Bu}$ bölümde çalışmadan elde edilen bulgular araştırmanın alt problemleri doğrultusunda ayrı başlıklar halinde sunulmuştur.

Matematik Başarı Testinden Elde Edilen Bulgular

EBA destekli öğretimin öğrencilerin matematik başarı üzerindeki etkisini incelemek için uygulama öncesinde öğrencilerin matematik başarısı açısından birbirlerine denk düzeyde olup olmadığını sınamak için matematik başarı testinin ön test olarak uygulanması ile elde edilen verilere bağımsız örneklemler t-testi uygulanmış ve bulgular Tablo 6'de verilmiştir.

Tablo 6. Deney ve kontrol grubu başarı ön test puanı t-testi sonucu

\begin{tabular}{lcccccc}
\hline Gruplar & N & $\overline{\mathbf{x}}$ & Ss & t & sd & p \\
\hline Deney Grubu & 25 & 40,80 & 11,608 & & & \\
\cline { 1 - 3 } Kontrol Grubu & 22 & 40,00 & 16,762 & 0,192 & 45 & 0,849 \\
\hline
\end{tabular}


Tablo 6'da görüldüğü gibi deney grubu ile kontrol grubunun arasında uygulama öncesinde başarı matematik başarı ön test sonuçları açısından bir farklılık bulunmamaktadır $[t(45)=0,192 ; p>0,05]$. Uygulamaya başlamadan önce deney ve kontrol gruplarının matematik başarı puanları düzeyinde birbirine denk olduğu görülmüştür. Uygulama sonrasında ise EBA destekli öğretimin matematik başarısı üzerindeki etkililiğini sınamak adına matematik başarı testi son test olarak uygulanmış ve elde edilen bulgular Tablo 7'de verilmiştir.

Tablo 7. Deney ve kontrol grubu başarı son test puanı t-testi sonucu

\begin{tabular}{lcccccc}
\hline Gruplar & $\mathbf{N}$ & $\overline{\mathbf{x}}$ & Ss & t & sd & p \\
\hline Deney Grubu & 25 & 57,40 & 14,077 & & & \\
Kontrol Grubu & 22 & 47,73 & 15,866 & 2,215 & 45 & 0,032 \\
\hline
\end{tabular}

Tablo 7'de görüldüğü deney grubu ile kontrol grubu arasında matematik başarı son test puanları açısından anlamlı bir farklılık vardır ve bu farklılığın deney grubu lehine olduğu görülmektedir $[t(45)=2,215 ; p<0,05]$. Bu bağlamda EBA destekli öğretim uygulanan öğrencilerin yer aldı̆̆ı deney grubu öğrencileri matematik başarı testinde diğer gruptan daha başarılı olduğu görülmüştür.

Gruplar arasında oluşan farkın büyüklüğüne dair eta kare $\left(\eta^{2}\right)$ değeri ile hesaplanmış ve $\eta^{2}=0,0983$ olarak bulunmuştur. Kilmen (2015)'e göre etki büyüklüğünün aldığı bu değerin anlamı ise orta derecede etkili olarak belirlenmiştir. Bir başka ifade ile EBA destekli öğretim grupların matematik başarılarının farklılaşması üzerinde orta derecede etkilidir.

\section{Matematiğe Yönelik Tutum Ölçeğinden Elde Edilen Bulgular}

EBA destekli öğretimin öğrencilerin matematiğe yönelik tutumları üzerindeki etkisini incelemek için uygulama öncesinde öğrencilerin matematiğe yönelik tutum açısından birbirlerine denk düzeyde olup olmadığını sınamak için matematiğe yönelik tutum ölçeği ön test olarak uygulanmıştır. Tablo 8'de gruplar arası matematiğe yönelik tutum ölçeği ön testine ait veriler bağımsız örneklemler t-testi ile analiz edilmiş ve bulgular verilmiştir.

Tablo 8. Deney ve kontrol grubu tutum ölçeği ön test puanı t-testi sonucu

\begin{tabular}{lcccccc}
\hline Gruplar & N & $\overline{\mathbf{x}}$ & Ss & t & sd & p \\
\hline Deney Grubu & 25 & 68,44 & 7,517 & & & \\
\cline { 1 - 4 } Kontrol Grubu & 22 & 68,27 & 8,113 & 0,073 & 45 & 0,942 \\
\hline
\end{tabular}

Tablo 8'de görüldüğü gibi deney grubu ile kontrol grubunun arasında uygulama öncesinde matematiğe yönelik tutum ölçeği ön test sonuçları açısından bir farklılık bulunmamaktadır $[t(45)=0,073 ; p>0,05]$. Uygulama sonrasında EBA destekli öğretimin gruplar arasında matematiğe yönelik tutum açısından bir değişiklik yaratıp yaratmadığını 
belirlemek amacıyla matematiğe yönelik tutum ölçeği ölçeği son test olarak uygulanmış ve elde edilen veriler bağımsız örneklemler t-testi ile analiz edilmiş ve bulgular Tablo 9'da sunulmuştur.

Tablo 9. Deney ve kontrol grubu tutum ölçeği son test puanı t-testi sonucu

\begin{tabular}{lcccccc}
\hline Gruplar & N & $\overline{\mathbf{x}}$ & Ss & t & sd & p \\
\hline Deney Grubu & 25 & 69,92 & 3,463 & & & \\
\cline { 1 - 3 } Kontrol Grubu & 22 & 68,36 & 6,052 & 1,009 & 45 & 0,278 \\
\hline
\end{tabular}

Tablo 9'da görüldüğü gibi deney grubu ile kontrol grubunun arasında uygulama sonunda matematiğe yönelik tutum ölçeği son test sonuçları açısından bir farklılık bulunmamaktadır $[t(45)=1,009 ; p>0,05]$. Bir başka ifadeyle EBA destekli öğretim yöntemi gruplar arasında matematiğe yönelik tutum açısından anlamlı olabilecek bir farklılık yaratmadığı görülmüştür.

\section{Matematik Dersine Yönelik Motivasyon Ölçeăinden Elde Edilen Bulgular}

EBA destekli öğretimin öğrencilerin matematik dersine yönelik motivasyonları üzerindeki etkisini incelemek için uygulama öncesinde öğrencilerin matematik dersine yönelik motivasyon açısından birbirlerine denk düzeyde olup olmadığını sınamak için matematik dersine yönelik motivasyon ölçeği ön test olarak uygulanmıştır. Tablo 10'da gruplar arası matematik dersine yönelik motivasyon ölçeği ön testine ait veriler bağımsız örneklemler t-testi ile analiz edilmiş ve bulgular verilmiştir.

Tablo 10. Deney ve kontrol grubu motivasyon ölçeği ön test puanı t-testi sonucu

\begin{tabular}{llccccc}
\hline Gruplar & $\mathbf{N}$ & $\overline{\mathbf{x}}$ & Ss & t & sd & p \\
\hline Deney Grubu & 25 & 87,36 & 3,463 & & & \\
\cline { 1 - 3 } Kontrol Grubu & 22 & 85,32 & 6,052 & 0,881 & 45 & 0,383 \\
\hline
\end{tabular}

Tablo 10'da görüldüğü gibi deney grubu ile kontrol grubunun arasında uygulama öncesinde matematik dersine yönelik motivasyon ölçeği ön test sonuçları açısından bir farklılık bulunmamaktadır $[t(45)=0,881 ; p>0,05]$. Uygulama sonrasında EBA destekli öğretimin gruplar arasında matematik dersine yönelik motivasyon açısından bir değişiklik yaratıp yaratmadığını belirlemek amacıyla matematik dersine yönelik motivasyon ölçeği son test olarak uygulanmış, elde edilen veriler bağımsız örneklemler t-testi ile analiz edilmiş ve bulgular Tablo 11'de sunulmuştur.

Tablo 11. Deney ve kontrol grubu motivasyon ölçeği son test puanı t-testi sonucu

\begin{tabular}{|c|c|c|c|c|c|c|}
\hline Gruplar & $\mathbf{N}$ & $\bar{x}$ & Ss & $t$ & sd & p \\
\hline Deney Grubu & 25 & 91,12 & 5,028 & & & \\
\hline Kontrol Grubu & 22 & 85,95 & 7,168 & 2,887 & 45 & 0,006 \\
\hline
\end{tabular}


Tablo 11'de görüldüğü deney grubu ile kontrol grubu sonrasında matematik dersine yönelik motivasyon son test puanları açısından anlamlı bir farklılık vardır ve bu farklılığın deney grubu lehine olduğu görülmektedir $[t(45)=2,887 ; p<0,05]$. Bu bağlamda EBA destekli öğretim uygulanan öğrencilerin yer aldığı deney grubu öğrencilerinin matematik dersine yönelik motivasyon ölçeği puanları diğer gruptan daha yüksek olduğu görülmüştür. Gruplar arasında oluşan farklılığın büyüklüğü hesaplanmış ve $\eta^{2}=0,1562$ olarak bulunmuştur. Kilmen (2015)'e göre etki büyüklüğünün aldığı bu değerin anlamı ise büyük derecede etkili olarak belirlenmiştir. Bir başka ifade ile EBA destekli öğretim grupların matematik dersine yönelik motivasyonlarının farklılaşması üzerinde yüksek derecede etkilidir.

\section{Tartışma, Sonuç ve Öneriler}

EBA dijital platformu ile desteklenen öğrenme ortamının öğrencilerin başarı üzerinde etkisi olup olmadığını belirlemek amacı ile ön test ve son test olarak uygulanan matematik başarı testinin analizinden ön testte gruplar arasında anlamlı bir fark olmadığı, son testte ise deney grubu lehine anlamlı bir fark olduğu sonucuna varılmıştır. Bir başka ifade ile EBA destekli öğrenme ortamının eşitlik ve denklem konusunda öğrencilerin matematik başarıları üzerinde etkili olduğu görülmüştür. Bu bulgu EBA ile desteklenen öğrenme ortamının öğrencilerin matematik başarısı üzerinde anlamlı ve olumlu bir etkiye sahip olduğunu ortaya koyan literatürdeki bazı araştırma sonuçları ile paralellik göstermektedir (Açıkgöz, 2018; Ertem-Akbaş, 2019; Özbey \& Koparan, 2019; Tekin, 2019; Vahit, 2019). Bununla birlikte bu araştırmada öğrencilerin matematik dersi başarıları ile elde edilen sonuç, EBA ile desteklenen öğrenme ortamının öğrencilerinin matematik başarılarında etkili olmadığını (Ankay, 2019; Kelismail, 2019; Türkmen \& Soybaş, 2019) ortaya koyan bazı araştırma sonuçları ile farklılık göstermektedir.

EBA dijital platformu ile desteklenen öğrenme ortamının öğrencilerin matematik dersine yönelik tutumları üzerinde etkisi olup olmadığını belirlemek amacı ile ön test ve son test olarak uygulanan tutum ölçeğinin analizinden ön testte ve son testte gruplar arasında anlamlı bir fark olmadığı sonucuna varılmıştır. Bir başka ifade ile EBA ile desteklenen öğrenme ortamı öğrencilerin matematiğe yönelik tutumları üzerinde etkili olmadığı sonucuna ulaşılmıştır. Bu sonuç, cebir öğretiminde EBA destekli matematik öğretiminin öğrencilerin matematiğe yönelik tutumları üzerinde etkili olmadığını ortaya koyan araştırmalar ile benzerlik göstermektedir (Ankay, 2019; Kelismail, 2019; Türkmen \& Soybaş, 
2019). Öte yandan EBA destekli öğrenme ortamının öğrencilerin matematiğe yönelik tutumları üzerinde anlamlı ve olumlu yönde etkili olduğunu (Vahit, 2019) ortaya koyan bazı araştırma sonuçları ile farklılık göstermektedir. Bu farklılıkların uygulama süreleri ve öğrencilerin EBA platformuna aşinalık durumları ile ilgili olduğu düşünülmektedir. Literatürde öğrencilerin matematiğe yönelik tutumlarında değişiklik meydana gelmesi için uzun bir zamanın gerekli olduğu (Herzig \& Kung, 2003) belirtilmektedir.

EBA dijital platformu ile desteklenen öğrenme ortamının öğrencilerin matematik dersine yönelik motivasyonları üzerinde etkisi olup olmadı ̆̆ını belirlemek amacı ile ön test ve son test olarak uygulanan matematik dersine yönelik motivasyon ölçeğinin analizinden ön testte gruplar arasında anlamlı bir fark olmadığı, son testte ise deney grubu lehine anlamlı bir fark olduğu sonucuna varılmıştır. Bir başka ifade ile EBA ile desteklenen öğrenme ortamının öğrencilerin matematik dersine yönelik motivasyonları üzerinde etkili olduğu sonucuna ulaşılmıştır. Literatüre bakıldığında Ertem-Akbaş (2019), EBA destekli matematik öğretiminin öğrencilerin matematik başarılarını anlamlı ve olumlu bir yönde arttırdığı sonucuna ulaşmış olup, matematik başarısı üzerindeki bu artışta öğrencilerin matematik dersine yönelik motivasyonlarının da artış göstermesinin etkili olduğu belirtmiştir. Benzer şekilde Aydınözü, Sözcü ve Akbaş (2016) EBA içeriklerinin kullanıldığı öğretim sonucunda öğrencilerin motivasyonlarının arttığı sonucuna ulaşmıştır. Bu çalışmalarda elde edilen sonuçlar ile araştırmamızın sonuçları benzerlik göstermektedir. Öte yandan İnam ve Ünsal (2017) web destekli matematik öğretiminin öğrencileri yeterince güdülemediği ve öğrencilerin motivasyonlarında bir artış sağlamadığı sonucuna ulaşılmış ve bu sonuç araştırmamızdan elde edilen sonuçlar ile farklılaşmaktadır.

$\mathrm{Bu}$ çalışmadan elde edilen sonuçlar; EBA destekli öğretimin matematik öğretiminde kullanılmasının, matematik başarısının ve matematik dersine olan motivasyonun artmasında etkili olabileceğini ortaya koymaktadır. Öte yandan EBA destekli matematik öğretiminin, matematiğe yönelik tutum üzerinde anlamlı bir etkisinin olmadığını da ortaya koymaktadır. Araştırmada elde edilen sonuçlar doğrultusunda; EBA destekli matematik öğretiminin yaygınlaştırılması, EBA destekli matematik öğretimi ile farklı konularda ve farklı seviyelerde (ilkokul, lise vb.) öğrenciler ile uygulamaların gerçekleştirilmesi ve EBA destekli matematik öğretimi uygulanarak matematik başarısı, matematiğe yönelik tutum, matematik dersine yönelik motivasyon değişkenleri dışında farklı değişkenler baz alınarak yeni çalışmaların yapılması önerilmektedir. 
Bilgilendirme

Bu çalışma Anıl ÖZBEY isimli yazarın Doç.Dr. Timur KOPARAN danışmanlığında hazırladığı yüksek lisans tezinden üretilmiştir.

Bu çalışmada kullanılan verilerin 2020 yılı öncesine ait olduğu araştırmacılar tarafından onaylanmıştır.

Yazar Katkı Beyanı

Anıl ÖZBEY: Literatür Tarama, Araştırma Dizaynı, Etkinlik Geliştirme, Veri Toplama ve Analizi, Uygulama, Ön Taslak Yazımı ve Düzenleme

Timur KOPARAN: Metodoloji, Danışmanlık ve Denetim, İnceleme-Yazma ve Düzenleme

\section{Kaynaklar}

Açıkgöz, G. (2018). Eğitim bilişim ă̆ı (EBA) destekli matematik öğretiminin 7. sını öğrencilerinin akademik başarısına etkisi. Yayımlanmamış Yüksek Lisans Tezi, Kastamonu Üniversitesi, Fen Bilimleri Enstitüsü, Kastamonu.

Alkan, T. \& Bilici, A. \& Akdur, T. E. \& Temizhan, O. \& Çiçek, H. (2011). Fırsatları artırma teknolojiyi iyileştirme hareketi (FATİH) Projesi. In 5th International Computer $\mathcal{E}$ Instructional Technologies Symposium (pp. 22-24).

Altun, M. (2005). İlköğretim İkinci Kademede Matematik Öğretimi. Bursa: Aktüel Yayınevi.

Ankay, E. (2019). 5e öğretim modeline dayalı eğitim bilişim ă̆ı (EBA) kullanımının 5. sınıf öğrencilerinin kesirlerle toplama ve çıkarma işlemleri konusundaki başarısına, tutumuna ve bilgilerinin kalıcılı̆̆ına etkisi. Yayımlanmamış Yüksek Lisans Tezi, Gazi Üniversitesi, Eğitim Bilimler Enstitüsü, Ankara.

Aydınözü, D. \& Sözcü, U. \& Akbaş, V. (2016). Coğrafya öğretiminde EBA içeriklerinin öğrenci başarısına etkisi. Karadeniz Sosyal Bilimler Dergisi, 8(15), 343-361.

Bond, T. G. \&Fox, C. M. (2007). Applying the rasch model: Fundamental measurement in the human sciences (2nd ed.). Hillsdale, NJ: Lawrence Erlbaum Associates.

Çepni, S. (2007). Araştırma ve proje çalışmalarına giriş. 3. Basım. Trabzon: Celepler Matbaacılık. Demirel, Ö. \& Yağcl, E. (2006). Principles and methods of instruction, Feza Journalism A.Ş.

Ertem-Akbaş, E. (2019). Eğitim Bilişim Ağ1 (EBA) destekli matematik öğretiminin 5. sinıf kesir konusunda öğrenci başarılarına etkisi. Journal of Computer and Education Research, 7(13), 120-145.

Eskrootchi, R. \& Oskrochi, G. R. (2010). A Study of the Efficacy of Project-based Learning Integrated with Computer-based Simulation - STELLA. Educational Technology $\mathcal{E}$ Society, 13(1), 236-245.

Fraenkel, J. R. \& Wallen, N. E. (2006). How to design and evaluate research in education (Sixth edition). Boston: McGraw-Hill Pub.

Herzig, A. \& Kung, D. T. (2003). Cooperative learning in calculus reform: what have we learned?. Research in Collegiate Mathematics Education. American Mathematical Society. 30- 50. 
George, D. \& Mallery, M. (2010). SPSS for windows step by step: a simple guide and reference 17.0 update (10 ed.). Boston: Pearson.

Gomez, E. A. \& Wu, D. \& Passerinic, K. (2010). Computer-supported team-based learning: The impact of motivation, enjoyment and team contributions on learning outcomes. Computers E Education, 55(1), 378-390.

İnam, A. \& Ünsal, H. (2017). Ortaokul 5.sınıf öğrencilerinin matematik uygulamaları dersinin web destekli öğretiminin öğrenci performans ve motivasyonuna etkisi ile öğrenci görüşlerinin değerlendirilmesi.Hasan Ali Yücel Egitim Fakültesi Dergisi, 14(1),155-169.

Kelismail, E. (2019). Ĕğitim Bilişim A $\breve{g ̆}_{\imath}(E B A)$ destekli öğretimin 6. stnı öğrencilerinin cebirsel ifadeler alt öğrenme alanında matematik başarılarına ve tutumlarına etkisi. Yayımlanmamış Yüksek Lisans Tezi, Gazi Üniversitesi, Eğitim Bilimler Enstitüsü, Ankara.

Kilmen, S. (2015). Eğitim Araştırmacıları için spss uygulamalı istatistik. Ankara: Edge Akademi.

Önal, N. (2013). Ortaokul öğrencilerinin matematik tutumlarına yönelik ölçek geliştirme çalışması. İlköğretim Online, 12(4), 938-94.

Özbey, A. \& Koparan, T. (2019). EBA ile desteklenen öğrenme ortamının ortaokul öğrencilerinin matematik dersi başarılarına etkisi. 3. Uluslararası Bilim ve Eğitim Kongresi. 21-24 Mart, 2019, Afyonkarahisar.

Pallant, J. (2007). SPSS survival manual, a step by guide to data analysis using spss for windows (Third edition). England: McGraw-Hill.

Pierson, M. E. (2001). Technology practice as a function of pedagogical expertise. Journal of Research on Computing in Education, 33(4), 413- 430.

Tekin, M. (2019). EBA destekli oran-orantı öğretiminin ders başarılarına ve üstbilişsel davranış algılarına etkisi. Yayımlanmamış Yüksek Lisans Tezi, Zonguldak Bülent Ecevit Üniversitesi, Fen Bilimleri Enstitüsü, Zonguldak.

Türker, A. \& Güven, C. (2016). Lise öğretmenlerinin eğitim bilişim ağı (EBA) projesinden yararlanma düzeyleri ve proje ile ilgili görüşleri. Ĕ̆itim ve Öğretim Araştırmaları Dergisi, 5(1), 244-254.

Türkmen, G. P. \& Soybaş, D. (2019). The effect of gamification methodology on students' achievements and attitudes towards mathematics. Bartin University Journal of Faculty of Education, 8(1), 258-298.

Üzel, D. \& Uyangör, N. \& Hasar, B. \& Çakır, Ö. (2018). Matematik dersine yönelik motivasyon ölçeği geliştirme çalışması. Journal of Social and Humanities Research, 5(18), 378-386.

Vahit, H. R. (2019). EBA etkinlikleriyle yapılan matematik öğretimin başarıya ve tutuma etkisi. Yayımlanmamış Yüksek Lisans Tezi, Kastamonu Üniversitesi, Fen Bilimleri Enstitüsü, Kastamonu.

Yılmaz, M. \& Üredi, L. \& Akbaşlı, S. (2015). Sınıf öğretmeni adaylarının bilgisayar yeterlilik düzeylerinin ve eğitimde teknoloji kullanımına yönelik algılarının belirlenmesi. International Journal of Humanities and Education, 1(1), 105-121.

Yılmaz, H. \& Düğenci, M. (2010). Hizmet içi eğitime farklı bir yaklaşım: e-hizmet içi eğitim. Muğla Üniversitesi. Akademik Bilişim Konferansı Bildirileri. ss. 67-74. 
Ek-1 Başarı testinden örnek sorular

Soru 1:

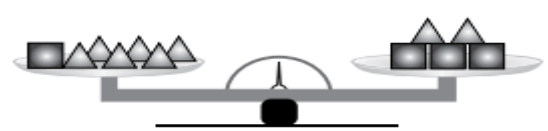

Yukarıdaki terazi dengededir. $\triangle$ sekli, 1 kilogramlık kütleyi gösterdiğine göre terazinin bir kefesindeki kütlelerin toplamı kaç kilogramdır?
A) 6
B) 8
C) 9
D) 10

Soru-8:

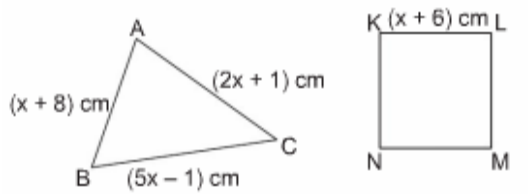

$A B C$ üçgeni ile KLMN karesinin çevresi eşit olduğuna göre x'in değeri kaçtır?
A) 9
B) 7
C) 6
D) 4

Soru 16

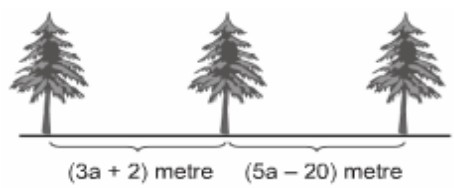

Yukarıdaki şekilde verilen her iki ağaç arası mesafe eşit olduğuna göre a'nın değeri kaçtır?
A) 5
B) 7
C) 9
D) 11

Soru-11:

Bir mahalledeki iki katı binaların sayısı, bir katl binaların sayısının 3 katının 2 eksiği kadar, üç katlı binaların sayısı, iki katlı binaların sayısının 2 katının 4 eksiği kadar ve aynı zamanda bir katlı binaların sayısının 4 katının 2 fazlası kadardır. Buna göre, bu mahalledeki üç katlı binaların sayısı kaçtır?
A) 13
B) 22
C) 26
D) 30

Ek 2. Etkinliklerden örnek sorular

\section{Etkinlik 4 Soru-3:}

"Bir anne 32, çocukları 8 ve 10 yaşındadır. Kaç yıl sonra annenin yaşı ile çocukların yaşları toplamı birbirine eşit olur?" ifadesinin çözümü için gerekli olan denklemi kuralım.

\section{Etkinlik-6 Soru-2}

Aşağıda verilen problemi denklem kurarak çözünüz.

*Bir sayının kendisi ile 2 katının toplamı, aynı sayının 5 katının 9 eksiğine eşit ise göre bu sayı kaçtır?

Etkinlik 3 Soru-1: Aşağıda verilen denklemlere uygun birer problem yazınız ve çözümünü yapınız.

\section{Denklem}

$(2 x)+(4 x-3)=33$
Problem

Etkinlik 2 Soru-6: Aşağıda verilen eşit kollu terazi dengede ise, denklem kurarak bilinmeyeni bulunuz.

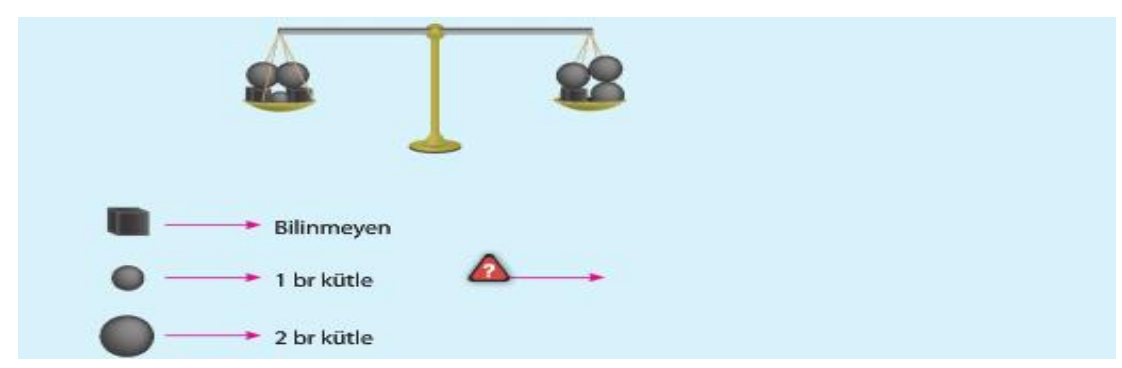

Etkinlik 5 Soru-1:Aşağıda problemlerde verilen yönergelere uyarak istenilenleri bulunuz.

ه) Emrénin yaşı, Gamze'nin yaşının 2 katının 3 fazlasıdır.

Emre ile Gamze'nin yaşları toplamı 33 olduğuna göre, Selen kaç yaşındadır?

a. Yukarıdaki problemin çözümünü veren denklemi yazınız.

b. Yazdığınız denklemi kullanarak sorunun cevabını veriniz.

JCER's Publication Ethics and Publication Malpractice Statement are based, in large part, on the guidelines and standards developed by the Committee on Publication Ethics (COPE). This article is available under Creative Commons CC-BY 4.0 license (https://creativecommons.org/licenses/by/4.0/) 